Check for updates

Cite this: RSC Adv., 2018, 8, 5523

\title{
Effect of Ti-doping on the electrochemical performance of sodium vanadium(III) phosphate
}

\author{
Bao Zhang, ${ }^{a}$ Tao Zeng, ${ }^{a}$ Yi Liü and Jia-feng Zhang (D) *a
}

$\mathrm{Na}_{3} \mathrm{~V}_{2-x} \mathrm{Ti}_{x}\left(\mathrm{PO}_{4}\right)_{3}(x=0.00,0.05,0.10$, and 0.15$)$ was successfully synthesized by a conventional solid-state route. The XRD results show that Ti is incorporated in the lattice of $\mathrm{Na}_{3} \mathrm{~V}_{2}\left(\mathrm{PO}_{4}\right)_{3}$ and the tetragonal structure has not been changed after doping. Among all the composites, the $\mathrm{Na}_{3} \mathrm{~V}_{1.9} \mathrm{Ti}_{0.1}\left(\mathrm{PO}_{4}\right)_{3}$ composite delivers the highest discharge capacity of $114.87 \mathrm{~mA} \mathrm{~h} \mathrm{~g}^{-1}$ at $0.1 \mathrm{C}$ and possesses a capacity retention of $96.23 \%$ after 20 cycles at $0.1 \mathrm{C}$, demonstrating the better rate performance and cycle stability in the potential range of 2.0-3.8 V. Electrochemical impedance spectroscopy (EIS) results reveal that the $\mathrm{Na}_{3} \mathrm{~V}_{1.9} \mathrm{Ti}_{0.1}\left(\mathrm{PO}_{4}\right)_{3}$ composite has a lower charge transfer resistance and a higher $\mathrm{Na}$-ion diffusion coefficient compared to other composites. The results indicate that Ti-doping in $\mathrm{Na}_{3} \mathrm{~V}_{2}\left(\mathrm{PO}_{4}\right)_{3}$ can effectively enhance the electrochemical performance of this tetragonal compound, especially at a high charge/discharge rate.

Received 24th November 2017 Accepted 22nd December 2017

DOI: $10.1039 / c 7 r a 12743 j$

rsc.li/rsc-advances

spaces, through which sodium ions can diffuse, have aroused much interest of many researchers. ${ }^{35,36}$

$\mathrm{Na}_{3} \mathrm{~V}_{2}\left(\mathrm{PO}_{4}\right)_{3}(\mathrm{NVP})$, which is a polyanionic material, has been greatly exploited ${ }^{37}$ for its several advantages: (1) good ionic mobility, (2) a high theoretical specific capacity (117.6 $\mathrm{mA} \mathrm{h} \mathrm{g}^{-1}$ ), (3) two very flat and stable redox electric potentials (3.4 and $1.6 \mathrm{~V}$ vs. $\mathrm{Na}^{+} / \mathrm{Na}$ ) based on the $\mathrm{V}^{4+} / \mathrm{V}^{3+}$ and $\mathrm{V}^{3+} / \mathrm{V}^{2+}$ redox couples, respectively. However, the stability of the structure of NVP also needs to be improved. It has been reported that transition metal doping is a useful way to improve the electrochemical performance of $\mathrm{Li}_{3} \mathrm{~V}_{2}\left(\mathrm{PO}_{4}\right)_{3} \cdot{ }^{38}$ Several cations, such as $\mathrm{Fe}^{3+},{ }^{39} \mathrm{Cr}^{3+},{ }^{40} \mathrm{Mg}^{2+},{ }^{41} \mathrm{Co}^{2+},{ }^{42}$ and $\mathrm{Ti}^{4+},{ }^{43}$ can be doped at the $\mathrm{V}$ site in the LVP, resulting in improved utilization of materials, high rate capabilities, electric conductivity, and cyclic stability. In the present work, we investigate aliovalent substitution of $\mathrm{V}^{\mathrm{III}}$ with $\mathrm{Ti}^{\mathrm{IV}}$ in NVP. So far, no studies have been done to dope titanium in NVP. We examine the effect of low levels of Ti doping on the electrochemical performance of NVP. The addition of titanium did not influence the structure of NVP, but the particle size was reduced and the electrical conductivity was improved, resulting in high capacity and rate capability. odium-ion batteries have become the focus in the field o energy and environment due to the abundance of sodium..$^{17,19-21}$

In recent years, many electrode materials such as $\mathrm{Na}_{x} \mathrm{CoO}_{2},{ }^{22}$ $\mathrm{Na}_{0.44} \mathrm{MnO}_{2},{ }^{23} \mathrm{NaV}_{6} \mathrm{O}_{15},{ }^{24} \mathrm{Na}_{1-x} \mathrm{Ni}_{0.5} \mathrm{Mn}_{0.5} \mathrm{O}_{2},{ }^{25} \mathrm{NaNi}_{1 / 3} \mathrm{Mn}_{1 / 3}$ $\mathrm{Co}_{1 / 3} \mathrm{O}_{2},{ }^{26} \quad \mathrm{NaFePO}_{4},{ }^{27} \quad \mathrm{NaFeSO}_{4} \mathrm{~F}^{28} \quad \mathrm{NaV}_{1-x} \mathrm{Cr}_{x} \mathrm{PO}_{4} \mathrm{~F}^{29}$ $\mathrm{Na}_{2} \mathrm{FePO}_{4} \mathrm{~F}^{30} \mathrm{Na}_{3} \mathrm{~V}_{2}\left(\mathrm{PO}_{4}\right)_{2} \mathrm{~F}_{3},{ }^{31} \mathrm{Na}_{2} \mathrm{Ti}_{3} \mathrm{O}_{7},{ }^{32,33}$ and $\mathrm{Na}_{2} \mathrm{C}_{8} \mathrm{H}_{4} \mathrm{O}_{4}$ (ref. 34) have been extensively investigated for sodium ion batteries. Recently, NASICON (for $\mathrm{Na}^{+}$superionic conductor)type electrode materials that can generate large interstitial

${ }^{a}$ School of Metallurgy and Environment, Central South University, Changsha, 410083, PR China.E-mail: yjyzjf@csu.edu.cn

${ }^{b}$ Tianjin Lishen Battery Joint-Stock Co., Ltd, Tianjin, 300384, PR China

\section{Experiment}

\subsection{Synthesis}

The $\mathrm{Na}_{3} \mathrm{~V}_{2-x} \mathrm{Ti}_{x}\left(\mathrm{PO}_{4}\right)_{3}(x=0.00,0.05,0.10,0.15)$ composites were synthesized by a conventional solid-state route. $\mathrm{NaH}_{2}$ $\mathrm{PO}_{4} \cdot 2 \mathrm{H}_{2} \mathrm{O}$ and $\mathrm{V}_{2} \mathrm{O}_{5}$ were used as the starting materials and ethanedioic acid was used as the reductant. In a typical synthesis process, $\mathrm{V}_{2} \mathrm{O}_{5}, \mathrm{NaH}_{2} \mathrm{PO}_{4} \cdot 2 \mathrm{H}_{2} \mathrm{O}$, nano-size $\mathrm{TiO}_{2}$, and $\mathrm{H}_{2} \mathrm{C}_{2} \mathrm{O}_{4}$ (in the appropriate amount) were mixed and ball-milled with alcohol media in a container of a planetary ball-mill at 


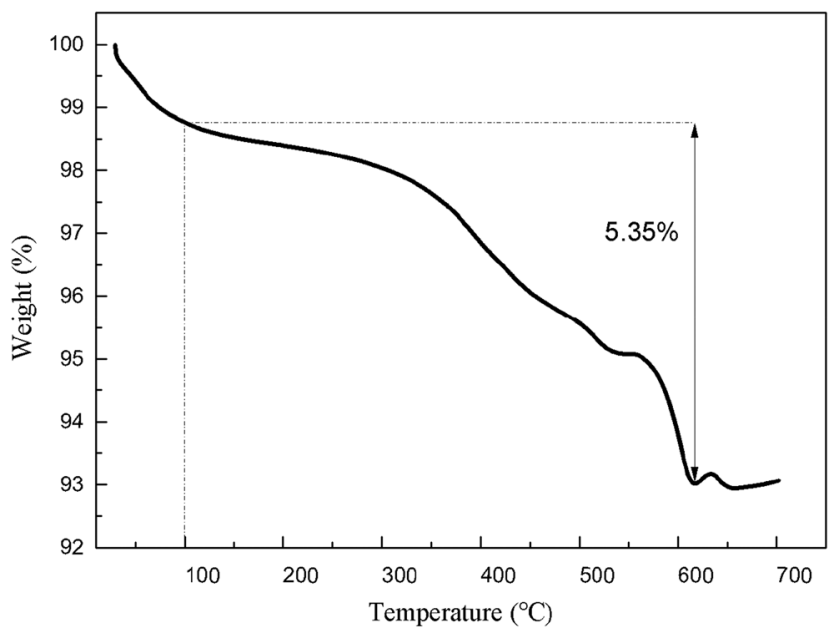

Fig. 1 The TGA curve of $\mathrm{Na}_{3} \mathrm{~V}_{1.9} \mathrm{Ti}_{0.1}\left(\mathrm{PO}_{4}\right)_{3}$.

$300 \mathrm{rpm}$ for $5 \mathrm{~h}$. After ball-milling, the obtained mixture was dried at $75^{\circ} \mathrm{C}$, then calcinated at $400{ }^{\circ} \mathrm{C}$ for $4 \mathrm{~h}$ and heated up to $750{ }^{\circ} \mathrm{C}$ and held there for $10 \mathrm{~h}$ in an atmosphere-controlled furnace under argon. The heating rate was $5{ }^{\circ} \mathrm{C} \min ^{-1}$. The $\mathrm{Na}_{3} \mathrm{~V}_{2-x} \mathrm{Ti}_{x}\left(\mathrm{PO}_{4}\right)_{3}(x=0.00,0.05,0.10,0.15)$ composites was obtained.

\subsection{Material characterization}

Thermogravimetric (TG/DSC) analysis of the mixture was measured on a SDT Q600 TG-DTA apparatus at temperature between 25 and $900{ }^{\circ} \mathrm{C}$ at a heating rate of $5{ }^{\circ} \mathrm{C} \mathrm{min}{ }^{-1}$ under argon flow. The powder X-ray diffraction (XRD, Rint-2000, Rigaku, Japan) measurement using $\mathrm{Cu} \mathrm{K} \alpha$ radiation was employed to identify the crystalline phases of the synthesized composites. XRD Rietveld refinement was analyzed by software (MAUD). The morphologies and chemical compositions of the composites were observed by scanning electron microscopy (SEM, JEOL, JSM-5600LV, Japan) and a energy dispersive X-ray (EDX) detector.

\subsection{Electrochemical performance tests}

The cathodes used for the electrochemical tests consisted of $80 \mathrm{wt} \%$ active material, $10 \mathrm{wt} \%$ acetylene black, and $10 \mathrm{wt} \%$ polyvinylidene fluoride (PVDF), which was used as the binder. $N$-Methyl-2-pyrrolidone (NMP) was used as a solvent and an aluminum foil as a current collector $\left(\sim 2.0 \mathrm{mg} \mathrm{cm}^{-2}\right)$. It was dried in a vacuum oven at $120{ }^{\circ} \mathrm{C}$ for $4 \mathrm{~h}$. Electrodes of the desired size were then punched out from the dried slurry. Electrochemical cells were assembled in a glove box filled with high-purity argon; pure sodium foil was used as the counter electrode. The electrolyte solution was $1 \mathrm{M} \mathrm{NaClO}_{4}$ (EC:DEC) $(1 \% \mathrm{VC})$ soaked in glass fiber separators (GF/D-Whatman). The test cells were galvanostatically cycled between 2.0 and $3.5 \mathrm{~V}$. $\mathrm{Na}^{+} / \mathrm{Na}$ at various C-rates based on the theoretical capacity of $118 \mathrm{~mA} \mathrm{~h} \mathrm{~g}{ }^{-1}$. The cyclic voltammetry (CV) profiles were recorded with a LK2005A electrochemical workstation (Lanlike Co., China). Electrochemistry impedance spectroscopy (EIS) was measured with an electrochemical workstation (CHI 660D) by applying an $\mathrm{AC}$ voltage of $5 \mathrm{mV}$ in the frequency range from 100 $\mathrm{kHz}$ to $0.04 \mathrm{~Hz}$.

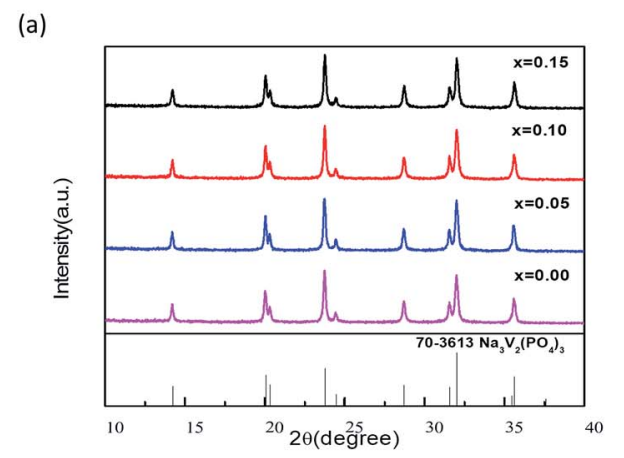

(b)

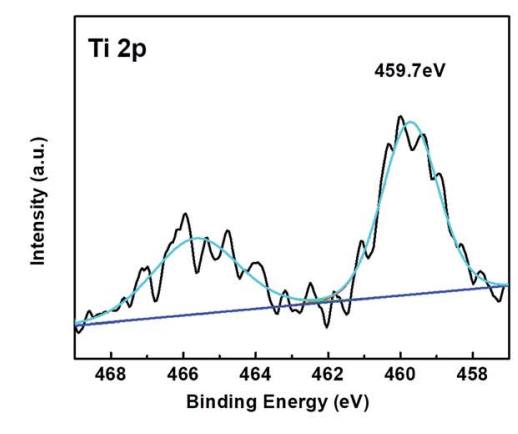

(c)

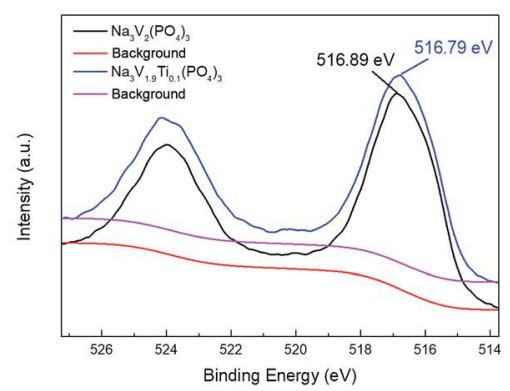

Fig. 2 (a) XRD patterns of $\mathrm{Na}_{3} \mathrm{~V}_{2-x} \mathrm{Ti}_{x}\left(\mathrm{PO}_{4}\right)_{3}(x=0.00,0.05,0.10,0.15)$ with various doping amount, (b) the XPS spectra of $\mathrm{Ti} 2 \mathrm{p}$ ( $\mathrm{Na} \mathrm{V}_{1.9}$ $\left.\mathrm{Ti}_{0.1}\left(\mathrm{PO}_{4}\right)_{3}\right)$, (c) the XPS spectra of $\mathrm{V} 2 \mathrm{p}\left(\mathrm{Na}_{3} \mathrm{~V}_{2}\left(\mathrm{PO}_{4}\right)_{3}\right.$ and $\left.\mathrm{Na}_{3} \mathrm{~V}_{1.9} \mathrm{Ti}_{0.1}\left(\mathrm{PO}_{4}\right)_{3}\right)$. 

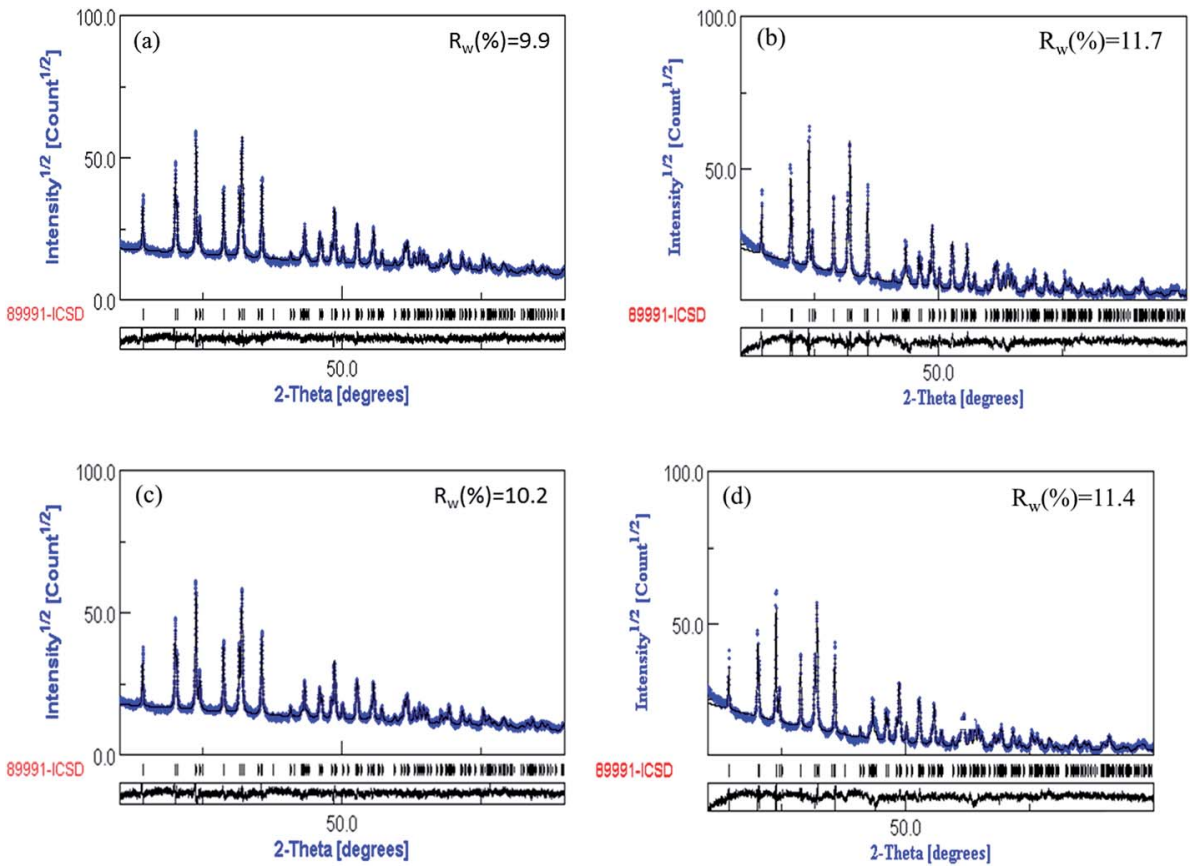

Fig. 3 Refinement XRD profiles for $\mathrm{Na}_{3} \mathrm{~V}_{2-x} \mathrm{Ti}_{x}\left(\mathrm{PO}_{4}\right)_{3}$. (a) $x=0.00$, (b) $x=0.05$, (c) $x=0.10$, (d) $x=0.15$.

Table 1 Lattice parameters of the pristine $\mathrm{Na}_{3} \mathrm{~V}_{2}\left(\mathrm{PO}_{4}\right)_{3}$ and $\mathrm{Na}_{3} \mathrm{~V}_{1.9^{-}}$ $\mathrm{Ti}_{0.1}\left(\mathrm{PO}_{4}\right)_{3}$ samples

\begin{tabular}{llllr}
\hline & $a(\AA)$ & $c(\AA)$ & Vol. $\left(\AA^{3}\right)$ & $R_{\mathrm{w}}(\%)$ \\
\hline $\mathrm{Na}_{3} \mathrm{~V}_{2}\left(\mathrm{PO}_{4}\right)_{3}$ & 8.72436 & 21.80602 & 1659.8 & 9.9 \\
$\mathrm{Na}_{3} \mathrm{~V}_{1.95} \mathrm{Ti}_{0.05}\left(\mathrm{PO}_{4}\right)_{3}$ & 8.72275 & 21.80401 & 1659.0 & 11.7 \\
$\mathrm{Na}_{3} \mathrm{~V}_{1.9} \mathrm{Ti}_{0.1}\left(\mathrm{PO}_{4}\right)_{3}$ & 8.71929 & 21.80088 & 1657.4 & 10.2 \\
$\mathrm{Na}_{3} \mathrm{~V}_{1.85} \mathrm{Ti}_{0.15}\left(\mathrm{PO}_{4}\right)_{3}$ & 8.72137 & 21.80135 & 1658.3 & 11.4
\end{tabular}

\section{Results and discussion}

Fig. 1 shows the TGA curve of $\mathrm{Na}_{3} \mathrm{~V}_{1.9} \mathrm{Ti}_{0.1}\left(\mathrm{PO}_{4}\right)_{3}$. The TGA test was taken in the oxygen. It was observed that the carbon content in the $\mathrm{Na}_{3} \mathrm{~V}_{1.9} \mathrm{Ti}_{0.1}\left(\mathrm{PO}_{4}\right)_{3}$ was $5.35 \%$.

XRD patterns of $\mathrm{Na}_{3} \mathrm{~V}_{2-x} \mathrm{Ti}_{x}\left(\mathrm{PO}_{4}\right)_{3}(x=0.00,0.05,0.10,0.15)$ with various amounts of Ti doping are shown in Fig. 2a. All the peaks are indexed to a single phase of tetragonal crystal type
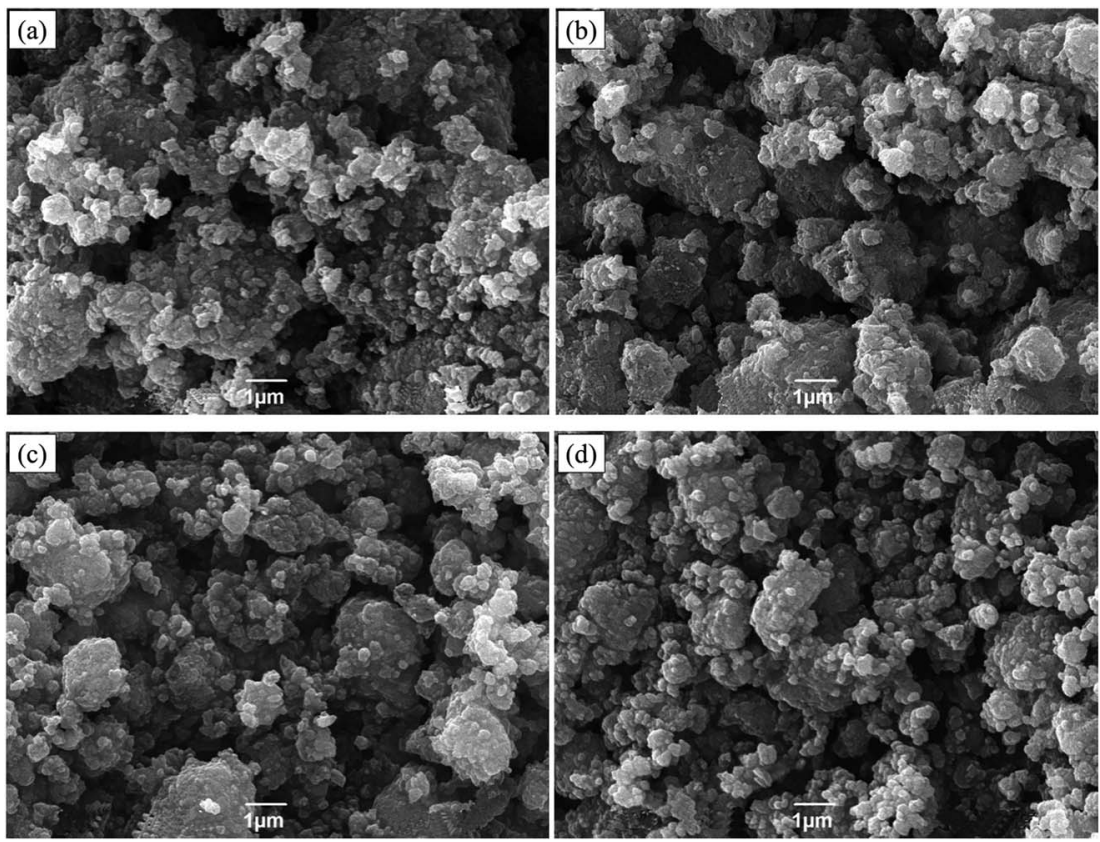

Fig. 4 SEM images of $\mathrm{Na}_{3} \mathrm{~V}_{2-x} \mathrm{Ti}_{x}\left(\mathrm{PO}_{4}\right)_{3}$. (a) $x=0.00$, (b) $x=0.05$, (c) $x=0.10$, (d) $x=0.15$. 

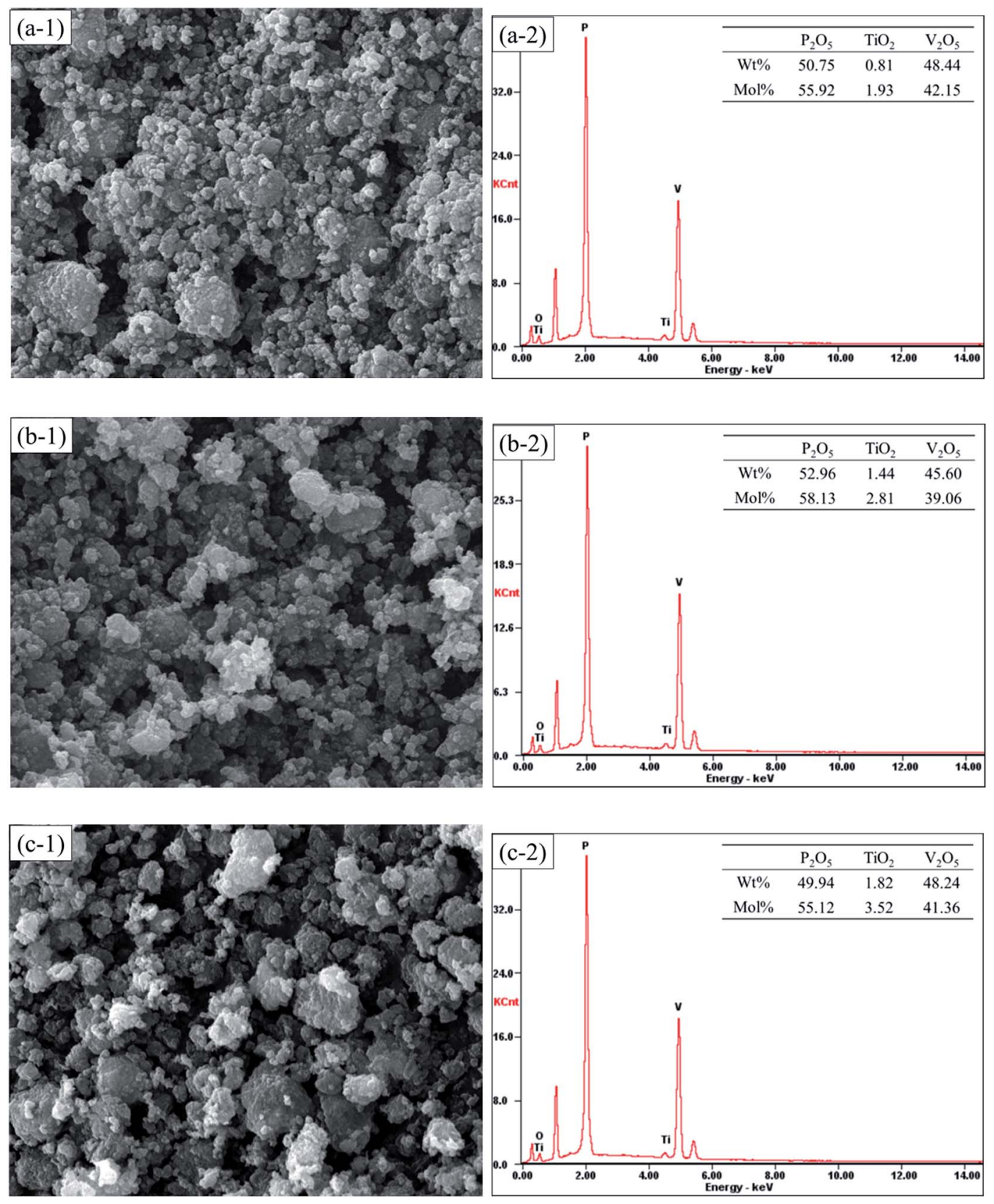

Fig. 5 EDX images of $\mathrm{Na}_{3} \mathrm{~V}_{2-x} \mathrm{Ti}_{x}\left(\mathrm{PO}_{4}\right)_{3}$. (a) $x=0.05$, (b) $x=0.10$, (c) $x=0.15$.

$\mathrm{Na}_{3} \mathrm{~V}_{2}\left(\mathrm{PO}_{4}\right)_{3}$, which is consistent with the references. It is clear that no impurity peaks such as Ti-doped composites are detected, indicating that the as-prepared composites are pure phase and the structure is unchanged after Ti doping. These sharp peaks in the patterns suggest good crystallinity of the powders.

The XPS spectra of Ti $2 \mathrm{p}\left(\mathrm{Na}_{3} \mathrm{~V}_{1.9} \mathrm{Ti}_{0.1}\left(\mathrm{PO}_{4}\right)_{3}\right)$ was shown in Fig. 2b. The binding energy of $\mathrm{Ti}$ in the picture to be $459.7 \mathrm{eV}$, matched well with some previous work, ${ }^{44}$ which indicate the valence of $\mathrm{Ti}$ in $\mathrm{Na}_{3} \mathrm{~V}_{1.9} \mathrm{Ti}_{0.1}\left(\mathrm{PO}_{4}\right)_{3}$ is +4 . The XPS spectra of $\mathrm{V} 2 \mathrm{p}$ $\left(\mathrm{Na}_{3} \mathrm{~V}_{2}\left(\mathrm{PO}_{4}\right)_{3}\right.$ and $\left.\mathrm{Na}_{3} \mathrm{~V}_{1.9} \mathrm{Ti}_{0.1}\left(\mathrm{PO}_{4}\right)_{3}\right)$ was shown in Fig. 2c. It is obviously that the binding energy of $\mathrm{V}$ in Ti-doping sample $\left(\mathrm{Na}_{3} \mathrm{~V}_{1.9} \mathrm{Ti}_{0.1}\left(\mathrm{PO}_{4}\right)_{3}\right)$ is $516.79 \mathrm{eV}$ and the binding energy of $\mathrm{V}$ in
$\mathrm{Na}_{3} \mathrm{~V}_{2}\left(\mathrm{PO}_{4}\right)_{3}$ is $516.89 \mathrm{eV}$, which means that the doping of titanium reduce the valence of $\mathrm{V}$. The result means that $\mathrm{Ti}$ is doped in the $\mathrm{V}$ site. ${ }^{45}$

Fig. 3 show the refined XRD data for $\mathrm{Na}_{3} \mathrm{~V}_{2-x} \mathrm{Ti}_{x}\left(\mathrm{PO}_{4}\right)_{3}(x=$ $0.00,0.05,0.10,0.15)$. The calculated pattern matched well with the PDF standard card. The refined lattice parameters and atomic coordination are listed in Table 1 . The $R_{\mathrm{w}}$ of $\mathrm{Na}_{3} \mathrm{~V}_{2-x^{-}}$ $\mathrm{Ti}_{x}\left(\mathrm{PO}_{4}\right)_{3}(x=0.00,0.05,0.10,0.15)$ were $9.9 \%, 11.7 \%, 10.2 \%$ and $11.4 \%$, respectively. The decrease of cell volume can be attributed to the insertion of $\mathrm{Ti}$, which is consistent with the previous result. ${ }^{44}$ As can be seen in Table 1 that the $\mathrm{Na}_{3} \mathrm{~V}_{1.9^{-}}$ $\mathrm{Ti}_{0.1}\left(\mathrm{PO}_{4}\right)_{3}$ had the smallest volumes. This indicates that the $\mathrm{Na}_{3} \mathrm{~V}_{1.9} \mathrm{Ti}_{0.1}\left(\mathrm{PO}_{4}\right)_{3}$ composites had smallest particle size. 


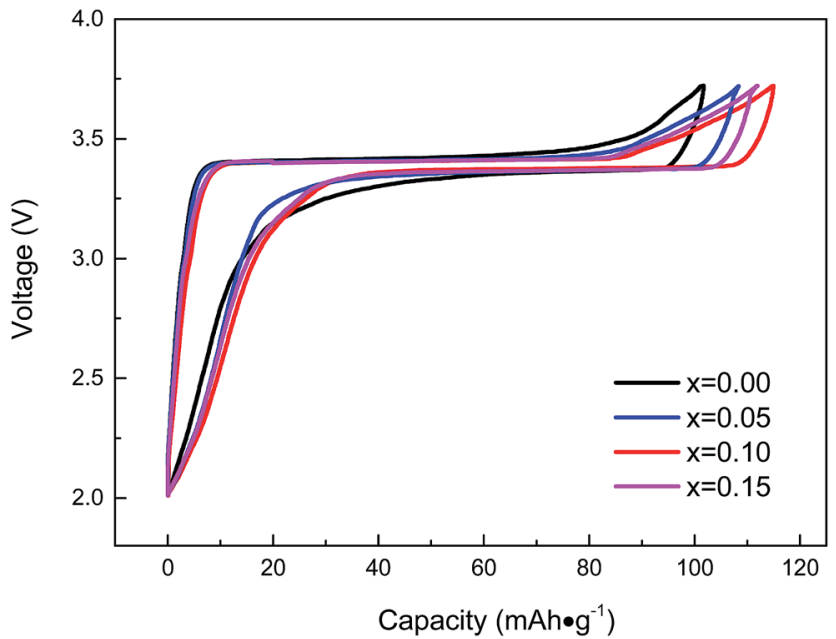

Fig. 6 Initial charge-discharge voltage profiles of $\mathrm{Na}_{3} \mathrm{~V}_{2-x} \mathrm{Ti}_{x}\left(\mathrm{PO}_{4}\right)_{3}(x$ $=0.00,0.05,0.10,0.15)$ at $0.1 \mathrm{C}$.

Fig. 4 shows the SEM images of $\mathrm{Na}_{3} \mathrm{~V}_{2-x} \mathrm{Ti}_{x}\left(\mathrm{PO}_{4}\right)_{3}(x=0.00$, $0.05,0.10,0.15)$. It's observed that the primary particles are in nano-scale and agglomerated to form secondary particles, showing similar irregular granular shapes. The results indicate a more homogeneous distribution of Ti-doping composites than the pristine one.

Fig. 5 shows the SEM images of $\mathrm{Na}_{3} \mathrm{~V}_{2-x} \mathrm{Ti}_{x}\left(\mathrm{PO}_{4}\right)_{3}(x=0.00$, $0.05,0.10,0.15)$. EDX was used to investigate the existed component elements in the composites. It can be seen in Fig. 5 that the element $\mathrm{Ti}$ is existed in $\mathrm{Na}_{3} \mathrm{~V}_{2-x} \mathrm{Ti}_{x}\left(\mathrm{PO}_{4}\right)_{3}(x=0.00$, $0.05,0.10,0.15)$, and the contents of Ti gradually increases with the rise of $\mathrm{Ti}$ concentrations, indicating that the $\mathrm{Na}_{3} \mathrm{~V}_{2-x} \mathrm{Ti}_{x^{-}}$ $\left(\mathrm{PO}_{4}\right)_{3}(x=0.00,0.05,0.10,0.15)$ composites was successfully synthesized.

Fig. 6 shows the initial charge-discharge voltage profiles of $\mathrm{Na}_{3} \mathrm{~V}_{2-x} \mathrm{Ti}_{x}\left(\mathrm{PO}_{4}\right)_{3}(x=0.00,0.05,0.10,0.15)$ at a current rate of $0.1 \mathrm{C}$ in the potential range of 2.0-3.8 $\mathrm{V}$. The curves indicate that two $\mathrm{Na}$ ions were extracted from/inserted into $\mathrm{Na}_{3} \mathrm{~V}_{2}\left(\mathrm{PO}_{4}\right)_{3}$ per formula unit during the charging/discharging processes, which lasted for 10 h. ${ }^{46}$ It can be seen from Fig. 6 that the charge curves for all cathodes exhibited a plateau at approximately $3.4 \mathrm{~V}$ and so did the corresponding discharge curves; these were attributed to the two-phase transitions occurring during the electrochemical reaction, which was agreed well with the CV curves as showed in Fig. 7. The initial discharge capacity of $\mathrm{Na}_{3} \mathrm{~V}_{2-x} \mathrm{Ti}_{x^{-}}$ $\left(\mathrm{PO}_{4}\right)_{3}$ composites $(x=0.00, x=0.05, x=0.10, x=0.15)$ are $102.58 \mathrm{~mA} \mathrm{~h} \mathrm{~g}^{-1}, 107.63 \mathrm{~mA} \mathrm{~h} \mathrm{~g}{ }^{-1}, 114.87 \mathrm{~mA} \mathrm{~h} \mathrm{~g}{ }^{-1}$ and $111.95 \mathrm{~mA} \mathrm{~h} \mathrm{~g}^{-1}$, respectively. The coulombic efficiency of the initial cycle is about $94.9 \%, 96.7 \%, 98.9 \%$ and $97.8 \%$, respectively. As can be seen from Fig. 6 that the capacities of Ti-doped $\mathrm{Na}_{3} \mathrm{~V}_{2-x} \mathrm{Ti}_{x}\left(\mathrm{PO}_{4}\right)_{3}(x=0.00,0.05,0.10,0.15)$ are higher than pristine $\mathrm{Na}_{3} \mathrm{~V}_{2}\left(\mathrm{PO}_{4}\right)_{3}$. In addition, the voltage difference of Tidoped $\mathrm{Na}_{3} \mathrm{~V}_{2-x} \mathrm{Ti}_{x}\left(\mathrm{PO}_{4}\right)_{3}$ is smaller than that of pristine $\mathrm{Na}_{3} \mathrm{~V}_{2}\left(\mathrm{PO}_{4}\right)_{3}$, resulting from the lower electrode polarization. It is clearly seen from Table 3 that $\mathrm{Na}_{3} \mathrm{~V}_{1.9} \mathrm{Ti}_{0.1}\left(\mathrm{PO}_{4}\right)_{3}$ exhibits the lowest polarization potential of $0.03 \mathrm{~V}$ with the best electrochemical performance and the highest initial discharge

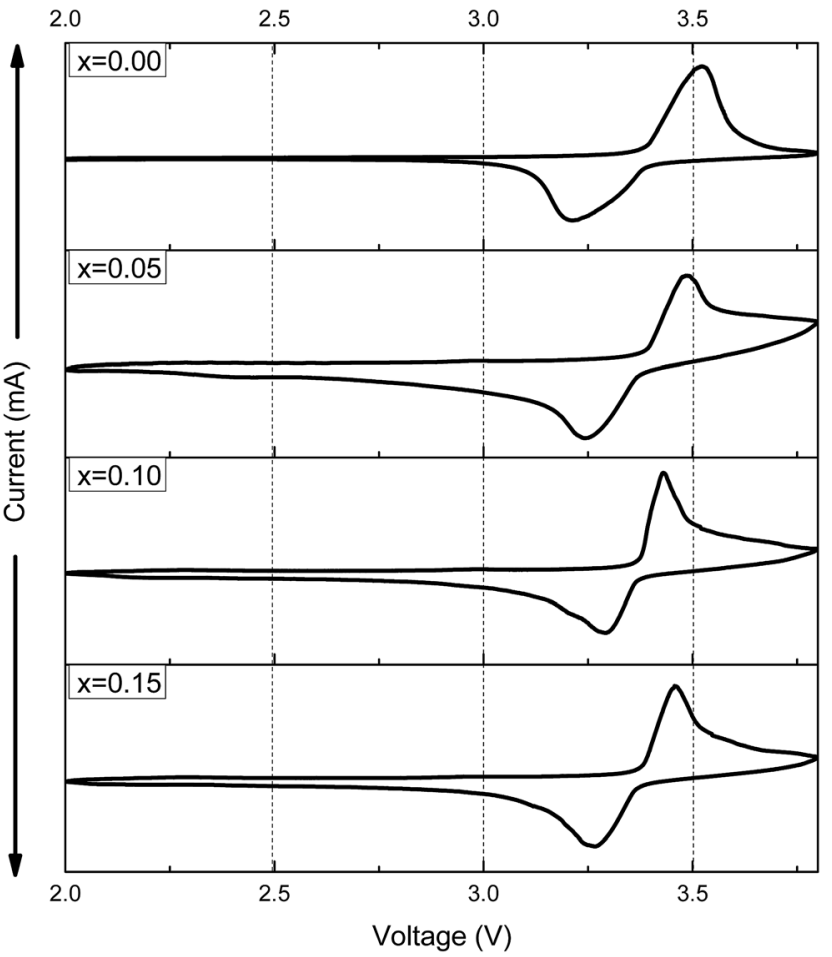

Fig. $7 \mathrm{CV}$ curves of $\mathrm{Na}_{3} \mathrm{~V}_{2-x} \mathrm{Ti}_{x}\left(\mathrm{PO}_{4}\right)_{3}(x=0.00,0.05,0.10,0.15)$ at $0.1 \mathrm{C}$.

capacity, indicating that Ti-doping does not block the tunnels of $\mathrm{Na}$ ions and probably increases the charge and discharge capacities and charge-discharge efficiency.

$\mathrm{CV}$ measurement was carried out at a scan rate of $0.1 \mathrm{mV} \mathrm{s}^{-1}$ to provide more information about the electrochemical properties, the second voltammograms (CV) of $\mathrm{Na}_{3} \mathrm{~V}_{2-x} \mathrm{Ti}_{x}\left(\mathrm{PO}_{4}\right)_{3}(x$ $=0.00,0.05,0.10,0.15)$ samples in the voltage range of $2.0-3.8 \mathrm{~V}$ are presented in Fig. 7. It can be observed that the CV curves are very similar. There are one oxidation peak and one reduction peak, corresponding to the relative $\mathrm{Na}^{+}$ion extraction and reinsertion. However, the $\mathrm{Na}^{+}$ion extraction and insertion processes for $\mathrm{Ti}$ doped samples are more stable, which is ascribed to relatively sharper peaks. Moreover, the $\mathrm{Na}_{3} \mathrm{~V}_{1.9^{-}}$ $\mathrm{Ti}_{0.1}\left(\mathrm{PO}_{4}\right)_{3}$ sample present the smallest potential differences between anodic and cathodic peaks, which is consistent with the result in charge-discharge voltage profiles, indicating the good reversibility of the $\mathrm{Na}^{+}$ion extraction/re-insertion and lower ohmic resistance in the electrode.

As shown in Fig. 8, five current densities, i.e. 0.1C, 0.5C, 1C, $2 \mathrm{C}$ and $5 \mathrm{C}$, are employed to evaluate the rate capability of $\mathrm{Na}_{3} \mathrm{~V}_{2-x} \mathrm{Ti}_{x}\left(\mathrm{PO}_{4}\right)_{3}(x=0.00,0.05,0.10,0.15)$ (charging current density is $0.1 \mathrm{C}$ ). It can be observed that the profiles reveal a large plateau at $3.4 \mathrm{~V}$ for discharge and the rate performance of the composites is highly affected by the Ti-doped content. Increasing Ti-doping amount first led to the enhancement of rate capability. It can be seen in Fig. 8 that Ti-doping samples show better rate performance than pristine $\mathrm{Na}_{3} \mathrm{~V}_{2}\left(\mathrm{PO}_{4}\right)_{3}$. Moreover, $\mathrm{Na}_{3} \mathrm{~V}_{1.9} \mathrm{Ti}_{0.1}\left(\mathrm{PO}_{4}\right)_{3}$ shows the best rate performance, delivering a capacity of $114.87 \mathrm{~mA} \mathrm{~h} \mathrm{~g}{ }^{-1}, 113.75 \mathrm{~mA} \mathrm{~h} \mathrm{~g}{ }^{-1}$, 

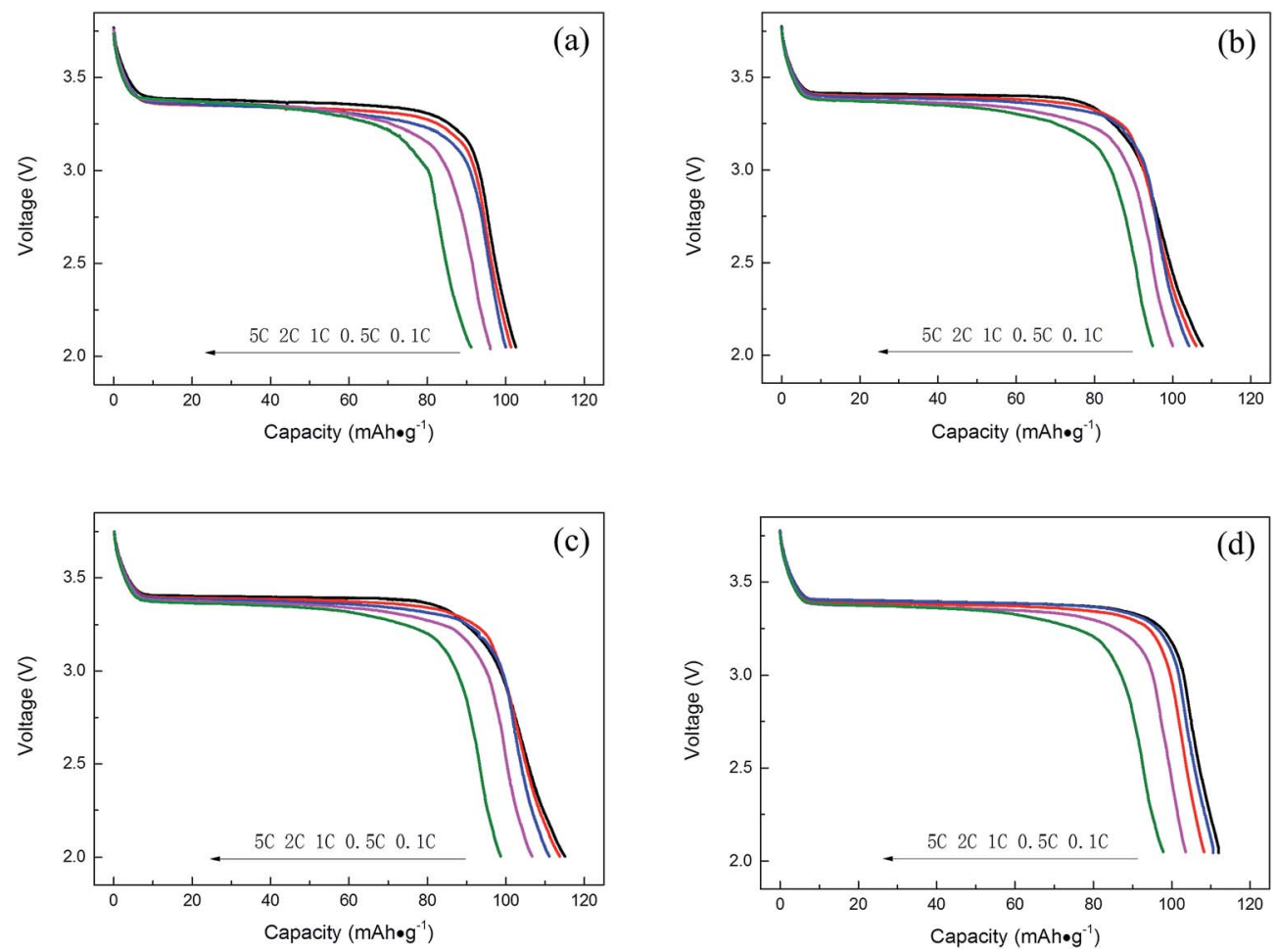

Fig. 8 The discharge curves of $\mathrm{Na}_{3} \mathrm{~V}_{2-x} \mathrm{Ti}_{x}\left(\mathrm{PO}_{4}\right)_{3}(x=0.00,0.05,0.10,0.15)$ at various rates. (a) $x=0.00,(\mathrm{~b}) x=0.05$, (c) $x=0.10$, (d) $x=0.15$.

111.07 $\mathrm{mA} \mathrm{h} \mathrm{g}^{-1}, 106.67 \mathrm{~mA} \mathrm{~h} \mathrm{~g}^{-1}$, and $98.63 \mathrm{~mA} \mathrm{~h} \mathrm{~g}^{-1}$. Moreover, the discharge voltage plateau of $\mathrm{Na}_{3} \mathrm{~V}_{1.9} \mathrm{Ti}_{0.1}\left(\mathrm{PO}_{4}\right)_{3}$ is still higher than $3.3 \mathrm{~V}$ at $5 \mathrm{C}$ rate, indicating that $\mathrm{Na}_{3} \mathrm{~V}_{1.9} \mathrm{Ti}_{0.1}\left(\mathrm{PO}_{4}\right)_{3}$ has a lower polarization. The results prove that Ti-doping can enhance the electrochemical performance.

All the $\mathrm{Na}_{3} \mathrm{~V}_{2-x} \mathrm{Ti}_{x}\left(\mathrm{PO}_{4}\right)_{3}(x=0.00,0.05,0.10,0.15)$ samples were cycled at five current densities $(0.1,0.5,1,2$, and $5 \mathrm{C})$ between 2.0 and $3.8 \mathrm{~V}$, and the results are shown in Fig. 9a. Each current density was tested for 5 cycles. It can be observed that the Ti-doping samples show a better rate performance than pristine $\mathrm{Na}_{3} \mathrm{~V}_{2}\left(\mathrm{PO}_{4}\right)_{3}$. Even so, a further increase of the titanium content was not as advantageous as for the former samples. Moreover, the rate performance of $\mathrm{Na}_{3} \mathrm{~V}_{1.9} \mathrm{Ti}_{0.1}\left(\mathrm{PO}_{4}\right)_{3}$ demonstrates the best among all samples, and it keeps a $97.02 \%$ at all rates, higher than that of the others. The sample with suitable
Ti-doping content $(x=0.10)$ shows the best rate performance compared with other samples. The results proved that Tidoping can improve the rate performance of $\mathrm{Na}_{3} \mathrm{~V}_{2}\left(\mathrm{PO}_{4}\right)_{3}$.

Fig. 9b shows the cycling performance of $\mathrm{Na}_{3} \mathrm{~V}_{2-x} \mathrm{Ti}_{x}\left(\mathrm{PO}_{4}\right)_{3}(x$ $=0.00,0.05,0.10,0.15)$ electrodes at $0.5 \mathrm{C}$. As can be seen from Fig. 9b that the Ti-doping samples, expect $\mathrm{Na}_{3} \mathrm{~V}_{2-x} \mathrm{Ti}_{x}\left(\mathrm{PO}_{4}\right)_{3}(x=$ 0.05), show a better cycling performance than pristine $\mathrm{Na}_{3} \mathrm{~V}_{2}\left(\mathrm{PO}_{4}\right)_{3}$. The discharge capacity of $\mathrm{Na}_{3} \mathrm{~V}_{2-x} \mathrm{Ti}_{x}\left(\mathrm{PO}_{4}\right)_{3}$ composites $(x=0.00, x=0.05, x=0.10, x=0.15)$ are $101.83 \mathrm{~mA} \mathrm{~h} \mathrm{~g}{ }^{-1}, 106.02 \mathrm{~mA} \mathrm{~h} \mathrm{~g}{ }^{-1}, 113.75 \mathrm{~mA} \mathrm{~h} \mathrm{~g}{ }^{-1}$ and $110.59 \mathrm{~mA} \mathrm{~h} \mathrm{~g}^{-1}$, respectively, and 94.59\%, 93.44\%, 96.70\% and $95.25 \%$ remained after 100 cycles in the range of $2.0-3.8 \mathrm{~V}$ at $0.5 \mathrm{C}$. The results indicate that suitable Ti-doping content $(x=$ $0.10, x=0.15)$ can enhance the cycling performance of $\mathrm{Na}_{3} \mathrm{~V}_{2}\left(\mathrm{PO}_{4}\right)_{3}$.
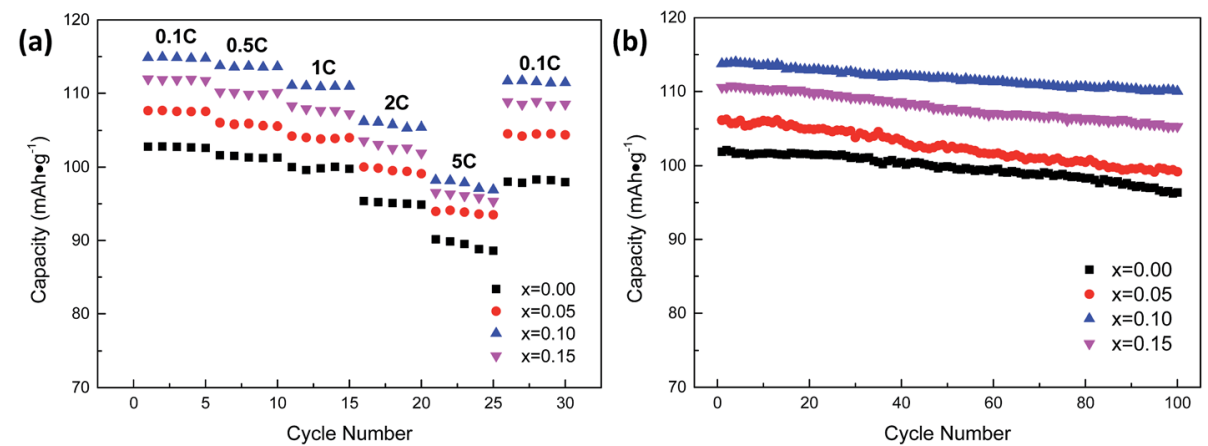

Fig. 9 (a) Discharge capacities of $\mathrm{Na}_{3} \mathrm{~V}_{2-x} \mathrm{Ti}_{x}\left(\mathrm{PO}_{4}\right)_{3}(x=0.00,0.05,0.10,0.15)$ samples at current densities of $0.1 \mathrm{C}, 0.5 \mathrm{C}, 1 \mathrm{C}, 2 \mathrm{C}$ and $5 \mathrm{C}$ in the voltage range of $2.0-3.8 \mathrm{~V}$, (b) cycling performance of $\mathrm{Na}_{3} \mathrm{~V}_{2-x} \mathrm{Ti}_{x}\left(\mathrm{PO}_{4}\right)_{3}(x=0.00,0.05,0.10,0.15)$ electrodes at $0.5 \mathrm{C}$. 

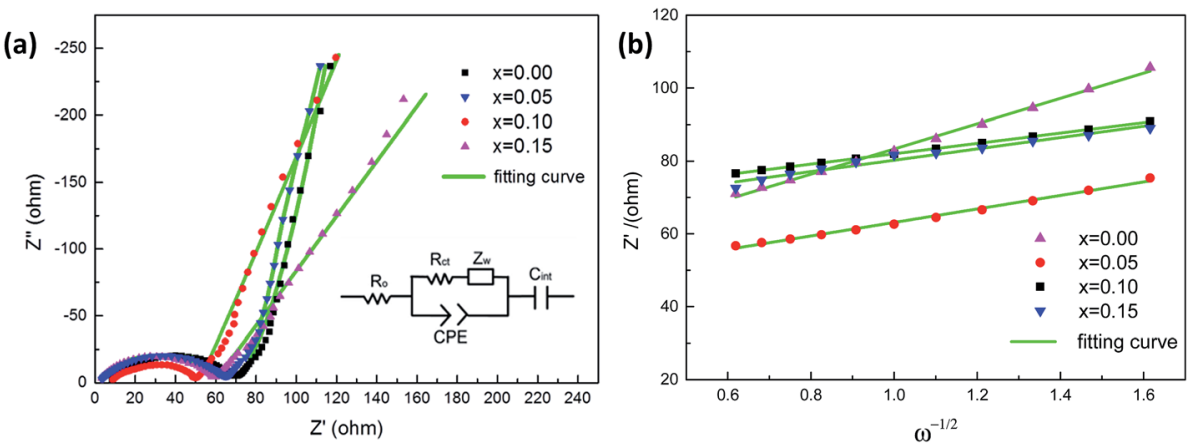

Fig. 10 (a) Nyquist plots of $\mathrm{Na}_{3} \mathrm{~V}_{2-x} \mathrm{Ti}_{x}\left(\mathrm{PO}_{4}\right)_{3}(x=0.00,0.05,0.10,0.15)$. Inset shows an equivalent circuit adopted to simulate the impedance spectra, (b) relationship between $Z_{0}$ and $\omega^{-1 / 2}$ in the low frequency region of $\mathrm{Na}_{3} \mathrm{~V}_{2-x} \mathrm{Ti}_{x}\left(\mathrm{PO}_{4}\right)_{3}(x=0.00,0.05,0.10,0.15)$.

Table 2 EIS simulation parameters of $\mathrm{Na}_{3} \mathrm{~V}_{2-x} \mathrm{Ti}_{x}\left(\mathrm{PO}_{4}\right)_{3}(x=0.00$, $0.05,0.10,0.15)$

\begin{tabular}{lllc}
\hline Samples & $R_{\mathrm{o}}\left(\Omega \mathrm{cm}^{-2}\right)$ & $R_{\mathrm{ct}}\left(\Omega \mathrm{cm}^{-2}\right)$ & $D_{\mathrm{Na}}\left(10^{-16}\right)$ \\
\hline$x=0.00$ & 7.36 & 61.01 & 5.98 \\
$x=0.05$ & 2.44 & 59.35 & 11.49 \\
$x=0.10$ & 7.41 & 44.75 & 14.53 \\
$x=0.15$ & 2.20 & 53.87 & 13.27
\end{tabular}

Fig. 10a presents the AC impedance spectra of $\mathrm{Na}_{3} \mathrm{~V}_{2-x^{-}}$ $\mathrm{Ti}_{x}\left(\mathrm{PO}_{4}\right)_{3}(x=0.00,0.05,0.10,0.15)$. The spectras show an intercept at a high frequency, followed by a depressed semicircle in the high-middle frequency region, and a straight line in the low frequency region. An equivalent circuit was conducted to refine the spectra. In the circuit, $R_{\mathrm{o}}$ represents the ohmic resistance of the electrolyte and electrode, as the intercept impedance on the $Z$-axis. CPE represents the double layer capacitance. $R_{\mathrm{ct}}$ is the charge transfer resistance, $Z_{\mathrm{w}}$ represents the diffusion-controlled Warburg impedance, and $C_{\text {int }}$ indicates the capacitance caused by the cumulation or loss of $\mathrm{Na}^{+}$in the crystal of electrode material. The parameters obtained from the equivalent circuit fitting are shown in Table 2 . It is found that the $R_{\text {ct }}$ of $\mathrm{Na}_{3} \mathrm{~V}_{2-x} \mathrm{Ti}_{x}\left(\mathrm{PO}_{4}\right)_{3}$ composites with $x=0.00, x=0.05, x=0.10, x=0.15$ are $61.01 \Omega$, $59.35 \Omega, 44.75 \Omega$ and $53.87 \Omega$, respectively, which indicates that Ti-doping can increase the charge transfer speed of the electrochemical reaction. Moreover, the minimum $R_{\mathrm{ct}}$ of $\mathrm{Na}_{3} \mathrm{~V}_{1.9} \mathrm{Ti}_{0.1}\left(\mathrm{PO}_{4}\right)_{3}$ results in its best electrochemical performance among all the samples.

The diffusion coefficient of lithium ions $\left(D_{\mathrm{Na}}\right)$ are calculated by equations. The results are also summarized in Table 2 .

$$
D_{\mathrm{Na}}=\frac{R^{2} T^{2}}{2 A^{2} F^{4} C_{\mathrm{Na}}^{2} \delta^{2}}
$$

Table 3 The initial charge-discharge overpotential of $\mathrm{Na}_{3} \mathrm{~V}_{2-x} \mathrm{Ti}_{x}-$ $\left(\mathrm{PO}_{4}\right)_{3}(x=0.00,0.05,0.10,0.15)$

\begin{tabular}{lllll}
\hline Samples & $x=0.00$ & $x=0.05$ & $x=0.10$ & $x=0.15$ \\
\hline Overpotential (V) & 0.11 & 0.06 & 0.03 & 0.05
\end{tabular}

where $R$, the gas constant, $T$, the absolute temperature, $A$, the surface area of the cathode, the number of electrons involved in the redox process, $F$, Faraday's constant, $C_{\mathrm{Na}}$, the concentration of sodium ion, so $\delta$ is the slope for the plot of $Z^{\prime}$ versus the reciprocal square root of the lower angular frequencies $\left(\omega^{-1 / 2}\right)$. To obtain the Warburg coefficient $(\delta)$, the linear fitting of $Z^{\prime}$ versus $\omega^{-1 / 2}$ is shown in Fig. 10b. All the parameters are listed in Table 2. It is seen that $\mathrm{Na}_{3} \mathrm{~V}_{1.9} \mathrm{Ti}_{0.1}\left(\mathrm{PO}_{4}\right)_{3}$ exhibit the highest value of $D_{\mathrm{Na}}$ among all the samples, which indicates that the electrochemical property of $\mathrm{Na}_{3} \mathrm{~V}_{2}\left(\mathrm{PO}_{4}\right)_{3}$ composites can be improved by an appropriate amount of $\mathrm{Ti}$ ion doping.

\section{Conclusion}

The $\mathrm{Na}_{3} \mathrm{~V}_{2-x} \mathrm{Ti}_{x}\left(\mathrm{PO}_{4}\right)_{3}(x=0.00,0.05,0.10,0.15)$ was successfully synthesized by a conventional solid state route. Based on the XRD refinement results, Ti has incorporated into the lattice of $\mathrm{Na}_{3} \mathrm{~V}_{2}\left(\mathrm{PO}_{4}\right)_{3}$. The amount of Ti doping has an important impact on electrochemical performance. In the electrochemical test, $\mathrm{Na}_{3} \mathrm{~V}_{1.9} \mathrm{Ti}_{0.1}\left(\mathrm{PO}_{4}\right)_{3}$ exhibits the best specific capacity of $114.87 \mathrm{~mA} \mathrm{~h} \mathrm{~g}^{-1}$ at $0.1 \mathrm{C}$ in the potential range of $2.0-3.8 \mathrm{~V}$ and possessing the capacity retention of $96.70 \%$ after 100 cycles at 0.5C. The Ti-added $\mathrm{Na}_{3} \mathrm{~V}_{2}\left(\mathrm{PO}_{4}\right)_{3}$ composites also show higher rate capability and cycle performance compared with the pristine $\mathrm{Na}_{3} \mathrm{~V}_{2}\left(\mathrm{PO}_{4}\right)_{3}$. The results of $\mathrm{CV}$ and EIS revealed that the doping titanium at an appropriate amount could increase the diffusion coefficient of sodium ions and result in the improvement of the reversibility of the materials. The results indicate that the Ti doping is an effective approach to achieve excellent electrochemical performance for the sodium ion pyrophosphate.

\section{Conflicts of interest}

There are no conflicts to declare.

\section{Acknowledgements}

We gratefully acknowledge the financial support for this work of the National Natural Science Foundation of China (General Program) under grant number 51272290 and 51402365. 


\section{References}

1 T. Ramireddy, M. M. Rahman, N. Sharma, et al., Carbon coated $\mathrm{Na}_{7} \mathrm{Fe}_{7}\left(\mathrm{PO}_{4}\right)_{6} \mathrm{~F}_{3}$ : A novel intercalation cathode for sodium-ion batteries, J. Power Sources, 2014, 271, 497-503.

2 C. Sun, S. Rajasekhara, J. B. Goodenough, et al., Monodisperse Porous $\mathrm{LiFePO}_{4}$ Microspheres for a High Power Li-Ion Battery Cathode, J. Am. Chem. Soc., 2011, 133(7), 2132-2135.

3 Y. Janssen, D. S. Middlemiss, S. Bo, et al., Structural Modulation in the High Capacity Battery Cathode Material $\mathrm{LiFeBO}_{3}$, J. Am. Chem. Soc., 2012, 134(30), 12516-12527.

$4 \mathrm{M}$. Konarova and I. Taniguchi, Synthesis of carbon-coated $\mathrm{LiFePO}_{4}$ nanoparticles with high rate performance in lithium secondary batteries, J. Power Sources, 2010, 195(11), 3661-3667.

5 E. Kobayashi, L. S. Plashnitsa, T. Doi, et al., Electrochemical properties of Li symmetric solid-state cell with NASICONtype solid electrolyte and electrodes, Electrochem. Commun., 2010, 12(7), 894-896.

6 A. Pan, D. Choi, J. Zhang, et al., High-rate cathodes based on $\mathrm{Li}_{3} \mathrm{~V}_{2}\left(\mathrm{PO}_{4}\right)_{3}$ nanobelts prepared via surfactant-assisted fabrication, J. Power Sources, 2011, 196(7), 3646-3649.

7 T. Jiang, W. Pan, J. Wang, et al., Carbon coated $\mathrm{Li}_{3} \mathrm{~V}_{2}\left(\mathrm{PO}_{4}\right)_{3}$ cathode material prepared by a PVA assisted sol-gel method, Electrochim. Acta, 2010, 55(12), 3864-3869.

8 M. Minakshi, P. Singh, N. Sharma, et al., Lithium ExtractionInsertion from/into $\mathrm{LiCoPO}_{4}$ in Aqueous Batteries, Ind. Eng. Chem. Res., 2011, 50(4), 1899-1905.

9 M. Minakshi, Lithium intercalation into amorphous $\mathrm{FePO}_{4}$ cathode in aqueous solutions, Electrochim. Acta, 2010, 55(28), 9174-9178.

10 F. Sauvage, L. Laffont, J. M. Tarascon, et al., Factors affecting the electrochemical reactivity $v s$. lithium of carbon-free $\mathrm{LiFePO}_{4}$ thin films, J. Power Sources, 2008, 175(1), 495-501.

11 M. Manickam, P. Singh, S. Thurgate, et al., Redox behavior and surface characterization of $\mathrm{LiFePO}_{4}$ in lithium hydroxide electrolyte, J. Power Sources, 2006, 158(1), 646-649.

12 G. J. Wang, N. H. Zhao, L. C. Yang, et al., Characteristics of an aqueous rechargeable lithium battery (ARLB), Electrochim. Acta, 2007, 52(15), 4911-4915.

13 A. Yuan and Q. Zhang, A novel hybrid manganese dioxide/ activated carbon supercapacitor using lithium hydroxide electrolyte, Electrochem. Commun., 2006, 8(7), 1173-1178.

14 A. Eftekhari, Electrochemical behavior of thin-film $\mathrm{LiMn}_{2}$ aqueous media, Electrochim. Acta, 2001, 47, 495-499.

$15 \mathrm{~J}$. Lee and $\mathrm{S}$. Pyun, Investigation of lithium transport through $\mathrm{LiMn}_{2} \mathrm{O}_{4}$ film electrode in aqueous $\mathrm{LiNO}_{3}$ solution, Electrochim. Acta, 2004, 49(5), 753-761.

$16 \mathrm{~J}$. Luo and Y. Xia, Aqueous Lithium-ion Battery $\operatorname{LiTi}_{2}\left(\mathrm{PO}_{4}\right)_{3} /$ $\mathrm{LiMn}_{2} \mathrm{O}_{4}$ with High Power and Energy Densities as well as Superior Cycling Stability, Adv. Funct. Mater., 2007, 17(18), 3877-3884.

17 F. Risacher and B. Fritz, Origin of Salts and Brine Evolution of Bolivian and Chilean Salars, Aquat. Geochem., 2009, 15(12), 123-157.
18 A. Yaksic and J. E. Tilton, Using the cumulative availability curve to assess the threat of mineral depletion: The case of lithium, Resour. Policy, 2009, 34(4), 185-194.

19 Y. Cao, L. Xiao, M. L. Sushko, et al., Sodium Ion Insertion in Hollow Carbon Nanowires for Battery Applications, Nano Lett., 2012, 12(7), 3783-3787.

20 P. Senguttuvan, G. Rousse, V. Seznec, et al., $\mathrm{Na}_{2} \mathrm{Ti}_{3} \mathrm{O}_{7}$ : Lowest Voltage Ever Reported Oxide Insertion Electrode for Sodium Ion Batteries, Chem. Mater., 2011, 23(18), 4109-4111.

21 S. Monica and L. L. Shaw, Advances and challenges of sodium ion batteries as post lithium ion batteries, $R S C$ Adv., 2015, 5, 53129-53154.

22 R. Berthelot, D. Carlier and C. Delmas, Electrochemical investigation of the $\mathrm{P} 2-\mathrm{Na}_{x} \mathrm{CoO}_{2}$ phase diagram, Nat. Mater., 2010, 10(1), 74-80.

23 Y. Cao, L. Xiao, W. Wang, et al., Reversible Sodium Ion Insertion in Single Crystalline Manganese Oxide Nanowires with Long Cycle Life, Adv. Mater., 2011, 23(28), 3155-3160.

24 T. H. J. U. Sebastian Wenzel, Room-temperature sodium-ion batteries: Improving the rate capability of carbon anode materials by templating strategies, Energy Environ. Sci., 2011, 4, 3342-3345.

25 S. Komaba, N. Yabuuchi, T. Nakayama, et al., Study on the Reversible Electrode Reaction of $\mathrm{Na}_{1-x} \mathrm{Ni}_{0.5} \mathrm{Mn}_{0.5} \mathrm{O}_{2}$ for a Rechargeable Sodium-Ion Battery, Inorg. Chem., 2012, 51(11), 6211-6220.

26 M. Sathiya, K. Hemalatha, K. Ramesha, et al., Synthesis, Structure, and Electrochemical Properties of the Layered Sodium Insertion Cathode Material: $\mathrm{NaNi}_{1 / 3} \mathrm{Mn}_{1 / 3} \mathrm{Co}_{1 / 3} \mathrm{O}_{2}$, Chem. Mater., 2012, 24(10), 1846-1853.

27 S. Oh, S. Myung, J. Hassoun, et al., Reversible $\mathrm{NaFePO}_{4}$ electrode for sodium secondary batteries, Electrochem. Commun., 2012, 22, 149-152.

28 J. E. C. N. Prabeer Barpanda and A. J. T. Michel Armand, Structural, Transport, and Electrochemical Investigation of Novel $\mathrm{AMSO}_{4} \mathrm{~F}(\mathrm{~A}=\mathrm{Na}, \mathrm{Li} ; \mathrm{M}=\mathrm{Fe}, \mathrm{Co}, \mathrm{Ni}, \mathrm{Mn})$ Metal Fluorosulphates Prepared Using Low Temperature Synthesis Routes, Inorg. Chem., 2010, 49, 7401-7413.

29 H. Zhuo, X. Wang, A. Tang, et al., The preparation of $\mathrm{NaV}_{1-x} \mathrm{Cr}_{x} \mathrm{PO}_{4} \mathrm{~F}$ cathode materials for sodium-ion battery, J. Power Sources, 2006, 160(1), 698-703.

30 Y. Kawabe, N. Yabuuchi, M. Kajiyama, et al., Synthesis and electrode performance of carbon coated $\mathrm{Na}_{2} \mathrm{FePO}_{4} \mathrm{~F}$ for rechargeable $\mathrm{Na}$ batteries, Electrochem. Commun., 2011, 13(11), 1225-1228.

31 T. Jiang, G. Chen, A. Li, et al., Sol-gel preparation and electrochemical properties of $\mathrm{Na}_{3} \mathrm{~V}_{2}\left(\mathrm{PO}_{4}\right)_{2} \mathrm{~F}_{3} / \mathrm{C}$ composite cathode material for lithium ion batteries, J. Alloys Compd., 2009, 478(1-2), 604-607.

32 A. Rudola, K. Saravanan, C. W. Mason, et al., $\mathrm{Na}_{2} \mathrm{Ti}_{3} \mathrm{O}_{7}$ : an intercalation based anode for sodium-ion battery applications, J. Mater. Chem. A, 2013, 1(7), 2653.

33 C. Y. Y. L. Wei Wang, Single crystalline $\mathrm{Na}_{2} \mathrm{Ti}_{3} \mathrm{O}_{7}$ rods as an anode material for sodium-ion batteries, $R S C A d v$., 2013, 3, 1041-1044.

34 L. Zhao, J. Zhao, Y. Hu, et al., Disodium Terephthalate $\left(\mathrm{Na}_{2} \mathrm{C}_{8} \mathrm{H}_{4} \mathrm{O}_{4}\right)$ as High Performance Anode Material for Low- 
Cost Room-Temperature Sodium-Ion Battery, Adv. Energy Mater., 2012, 2(8), 962-965.

35 C. Chen, F. Kun, L. Yao, et al., Use of a tin antimony alloyfilled porous carbon nanofiber composite as an anode in sodium-ion batteries, $R S C A d v$. , 2015, 5, 30793-30800.

36 M. Xu, C. Cheng, Q. Sun, et al., A 3D porous interconnected $\mathrm{NaVPO}_{4} \mathrm{~F} / \mathrm{C}$ network: preparation and performance for Naion batteries, RSC Adv., 2015, 5(50), 40065-40069.

37 V. O. Palomares, P. Serras, I. Villaluenga, et al., Na-ion batteries, recent advances and present challenges to become low cost energy storage systems, Energy Environ. Sci., 2012, 5, 5884-5901.

38 M. Choi, K. Kang, H. Kim, et al., The effect of titanium in $\mathrm{Li}_{3} \mathrm{~V}_{2}\left(\mathrm{PO}_{4}\right)_{3} /$ graphene composites as cathode material for high capacity Li-ion batteries, RSC Adv., 2015, 5(7), 48724879.

39 M. Ren, Z. Zhou, Y. Li, et al., Preparation and electrochemical studies of Fe-doped $\mathrm{Li}_{3} \mathrm{~V}_{2}\left(\mathrm{PO}_{4}\right)_{3}$ cathode materials for lithium-ion batteries, J. Power Sources, 2006, 62(2), 1357-1362.

40 Y. Chen, Y. Zhao, X. An, et al., Preparation and electrochemical performance studies on Cr-doped
$\mathrm{Li}_{3} \mathrm{~V}_{2}\left(\mathrm{PO}_{4}\right)_{3}$ as cathode materials for lithium-ion batteries, Electrochim. Acta, 2009, 54(24), 5844-5850.

41 C. Dai, Z. Chen, H. Jin, et al., Synthesis and performance of $\mathrm{Li}_{3}\left(\mathrm{~V}_{1-x} \mathrm{Mg}_{x}\right)_{2}\left(\mathrm{PO}_{4}\right)_{3}$ cathode materials, J. Power Sources, 2010, 195(17), 5775-5779.

42 Q. Kuang, Y. Zhao, X. An, et al., Synthesis and electrochemical properties of Co-doped $\mathrm{Li}_{3} \mathrm{~V}_{2}\left(\mathrm{PO}_{4}\right)_{3}$ cathode materials for lithium-ion batteries, Electrochim. Acta, 2010, 55(5), 1575-1581.

43 S. M. Stankov, I. Abrahams, A. Momchilov, et al., Effect of Tidoping on the electrochemical performance of lithium vanadium(III) phosphate, Ionics, 2015, 21(6), 1501-1508.

44 A. R. Burke, C. R. Brown, W. C. Bowling, et al., Ignition mechanism of the titanium-boron pyrotechnic mixture, Surf. Interface Anal., 1988, 11(6-7), 353-358.

45 M. Choi, K. Kang, H. Kim, et al., The effect of titanium in $\mathrm{Li}_{3} \mathrm{~V}_{2}\left(\mathrm{PO}_{4}\right)_{3} /$ graphene composites as cathode material for high capacity Li-ion batteries, RSC Adv., 2015, 5(7), 48724879.

46 G. Li, D. Jiang, H. Wang, et al., Glucose-assisted synthesis of $\mathrm{Na}_{3} \mathrm{~V}_{2}\left(\mathrm{PO}_{4}\right)_{3} / \mathrm{C}$ composite as an electrode material for highperformance sodium-ion batteries, J. Power Sources, 2014, 265, 325-334. 